Analysis

\title{
Valuing ecosystem services from wetlands restoration in the Mississippi Alluvial Valley
}

\author{
W. Aaron Jenkins ${ }^{\mathrm{a}, *}$, Brian C. Murray ${ }^{\mathrm{a}}$, Randall A. Kramer ${ }^{\mathrm{b}}$, Stephen P. Faulkner ${ }^{\mathrm{c}}$ \\ a Nicholas Institute for Environmental Policy Solutions, Duke University, Box 90335, Durham, NC 27708-0328, USA \\ ${ }^{\mathrm{b}}$ Nicholas School of the Environment, Duke University, Box 90328, Durham, NC 27708-0328, USA \\ c U.S. Geological Survey, National Wetlands Research Center, 700 Cajundome Blvd., Lafayette, LA 70506, USA
}

\section{A R T I C L E I N F O}

\section{Article history:}

Received 20 July 2009

Received in revised form 20 November 2009

Accepted 22 November 2009

Available online 8 January 2010

\section{Keywords:}

Ecosystem service

Economic valuation

Wetlands Reserve Program

Ecosystem markets

Social value

Market value

\begin{abstract}
A B S T R A C T
This study assesses the value of restoring forested wetlands via the U.S. government's Wetlands Reserve Program (WRP) in the Mississippi Alluvial Valley by quantifying and monetizing ecosystem services. The three focal services are greenhouse gas (GHG) mitigation, nitrogen mitigation, and waterfowl recreation. Site- and region-level measurements of these ecosystem services are combined with process models to quantify their production on agricultural land, which serves as the baseline, and on restored wetlands. We adjust and transform these measures into per-hectare, valuation-ready units and monetize them with prices from emerging ecosystem markets and the environmental economics literature. By valuing three of the many ecosystem services produced, we generate lower bound estimates for the total ecosystem value of the wetlands restoration. Social welfare value is found to be between $\$ 1435$ and $\$ 1486 /$ ha/year, with GHG mitigation valued in the range of $\$ 171$ to $\$ 222$, nitrogen mitigation at $\$ 1248$, and waterfowl recreation at $\$ 16$. Limited to existing markets, the estimate for annual market value is merely $\$ 70 /$ ha, but when fully accounting for potential markets, this estimate rises to $\$ 1035 /$ ha. The estimated social value surpasses the public expenditure or social cost of wetlands restoration in only 1 year, indicating that the return on public investment is very attractive for the WRP. Moreover, the potential market value is substantially greater than landowner opportunity costs, showing that payments to private landowners to restore wetlands could also be profitable for individual landowners.
\end{abstract}

(c) 2009 Elsevier B.V. All rights reserved.

\section{Introduction}

Ecosystem services, a collective term for the goods and services produced by ecosystems that benefit humankind, have traditionally been undervalued as they often fall outside of conventional markets (NRC, 2005). Without market prices, the incentive to provide them privately has been low relative to competing land uses, such as crops or timber. Reinforcing this notion, the Millennium Ecosystem Assessment reported that about $60 \%$ of global ecosystem services are being degraded or used unsustainably (MEA, 2005). Increasingly, society is recognizing the essential link between healthy ecosystems and human welfare and seeks ways to increase the provision of ecosystem services.

In recent decades, U.S. agricultural policy has implemented programs that offer financial incentives to private landowners to spur restoration of natural habitat and its attendant ecosystem services. A younger sibling of the Conservation Reserve Program (CRP), the Wetlands Reserve Program (WRP) focuses specifically on the restoration, protection, and enhancement of wetlands on private land through strategic public payments to landowners as well as

\footnotetext{
* Corresponding author. Tel.: +1 919613 8729; fax: +1 9196686444 E-mail addresses: wj14@duke.edu (W.A. Jenkins), bcmurray@duke.edu (B.C. Murray), kramer@duke.edu (R.A. Kramer), sfaulkner@usgs.gov (S.P. Faulkner).
}

increased collaboration between landowners and government agencies. Originally authorized in 1985, the acreage cap for WRP was expanded to 2.275 million acres in the 2002 Farm Security and Rural Investment Bill (USDA-NRCS, 2007).

This study focuses on the restoration of wetland ecosystem services in the Mississippi Alluvial Valley (MAV), the floodplain area below the confluence of the Mississippi and Ohio Rivers and principally located in the states of Arkansas, Mississippi, and Louisiana. These are the top three states in terms of WRP enrollment (USDA-NRCS, 2007). Once containing nearly 10 million hectares (Mha) of bottomland hardwood forest, the MAV had only 2.8 Mha remaining by the 1980 s following many decades of hydrological alteration and agricultural expansion (King et al., 2006). The major land use of the region is now agriculture, dominated by cultivation of corn, cotton, rice, and soybeans (USDA-NASS, 2009). This landscape transformation has had profound ecological consequences, such as wildlife habitat loss and fragmentation, loss of flood storage, and water quality degradation due to nonpoint source runoff.

Due to human impact on ecosystems, efforts to maintain and restore ecosystems require an improved understanding of how humans benefit from ecosystems as well as how human behavior can be influenced through conservation payments and other policy tools (Heal, 2000; Kramer, 2007). As a growing body of research examines ecosystem services and their valuation, government agencies are searching for 
ways to incentivize the provision of those services (Ricketts et al., 2004; Barbier, 2007; US EPA, 2002). Economists have been measuring ecosystem service values for years; for example, as part of legal proceedings to assess and assign natural resource damages from oil spills and other environmental accidents (Carson et al., 1994; NRC, 2005). Enthusiasm for ecosystem services, however, expanded to the broader scientific and policy community due in part to two widely influential works published in 1997 by Daily (1997) and Costanza et al. (1997). The Costanza et al. article sought to estimate the economic value of earth's ecosystems in their entirety. Most economists since then have followed the counsel of Toman (1998) to focus on valuing changes in specific ecosystem service flows, as does this paper.

Two recent articles have conducted statistical meta-analyses of wetland valuation studies, using wetland value per unit area as the dependent variable. Updated to 2008 U.S. dollars, the Woodward and Wui (2001) found a mean annual value per hectare of $\$ 567$ among its constituent studies, whereas Brander et al. (2006) computed a mean of over $\$ 4000 /$ ha/year with a median of $\$ 215$. Out of all the individual wetland services, only bird watching (Woodward and Wui) had a statistically significant and positive effect on the value of wetlands providing that service. Neither study reported GHG mitigation as a service.

Several studies have examined the participation in or benefits resulting from federal programs, such as CRP and WRP. Feather and Hellerstein (1997) evaluated the national benefits of reduced soil erosion for recreation and found that $11 \%$ or about $\$ 40$ million, of those benefits are attributable to the CRP. Ahearn et al. (2006) reported a conservative non-use value of $\$ 33$ million per year for increases in Central Plains grassland bird populations due to the CRP. Anderson and Parkhurst (2004) considered farmers' decisions to continue commodity crop production or to enroll in the WRP in the delta region of Mississippi and found that land was more likely to go into WRP if it had a lower return crop base and had considerable recreational value.

Given that the effectiveness of the WRP in achieving its restoration goals in the MAV is unknown, this study aims to assess the value to society of actions to restore wetlands there. This objective is accomplished primarily by comparing the economic values of ecosystem services produced on two land use types, cropland and restored wetlands. Constructing values from the bottom up, this study exploits a unique link between field data, process models, and economic valuation. Although the flows of ecosystem services are myriad, we select three focal services: GHG mitigation, nitrogen mitigation, and waterfowl recreation, each representing positive externalities from wetlands at different geographical scales-global, regional, and local, respectively. Furthermore, out of the services measured, these three services are those most likely to see markets developed for them (or to already have a market). By providing empirical measures of service flows and values for an important ecosystem, the findings of this analysis can provide valuable input into public and private decision making on natural resource management, including an assessment of the impact of the WRP.

\section{Background}

\subsection{Study Area}

The Mississippi Alluvial Valley (MAV) is the largest floodplain in the U.S., extending from below the confluence of the Mississippi and Ohio Rivers to southern Louisiana (Fig. 1). About three-quarters of the original bottomland hardwood forests have been converted, principally to row crop agriculture, while the remaining quarter is fragmented into over 38,000 discrete patches larger than 2 ha in size (Twedt and Loesch, 1999). The study area encompasses all of the counties that intersect with the MAV, save for those in Louisiana bordering the Gulf of Mexico.

\subsection{Benefit Valuation Process}

There are three essential steps in the ecosystem service valuation sequence: (1) identify the service, (2) quantify the service flows, and (3) monetize those flows. Disciplines that assess biophysical processes, such as ecology, biogeochemistry, and hydrology, play the central role in moving from identification to quantification, while economics provides the link from service quantification to monetization. The conceptual model of ecosystem service valuation used in this study is explained in Murray et al. (2009). Critical to bridging the biophysical and human aspects of ecosystem services is to transform the service flow data into valuation-ready measures. This transformation may involve integrating field observations with existing process models as well as modeling the service through time. We standardize the service measures into per-hectare values to facilitate comparisons with economic returns from other land uses and the aggregation of benefits at broader scales.

Because valuation needs are more abundant than the time and resources to develop them, benefit transfer methods apply results from previous primary research to new contexts (Rosenberger and Loomis, 2003). An accurate benefit transfer requires that the original study site be comparable to the targeted policy site with respect to the ecosystem service definition, the market context, and the welfare measure employed (Loomis and Rosenberger, 2006) or that the transferred value can be adjusted to reflect important differences between sites (e.g., using a value transfer). Using benefit transfer (Wilson and Hoehn, 2006), we multiply biophysical values for services of interest by shadow prices for the services. These shadow prices are obtained either through market price observations or from estimates of the service's benefits or costs from the environmental economics literature. To better inform public and private conservation decisions, this study also exploits the important dichotomy in economic values between social welfare value and market value. The first represents the economic value to society of the flow of ecosystem services and can be used in social benefit-cost analyses of public policies or programs. Market value embodies what landowners can capture through the market system and can be used to inform the design of landowner incentive programs for ecosystem protection or for the development of new markets for ecosystem services.

Agricultural land use is treated as the baseline activity in this analysis, since it represents the dominant land use in the MAV and thus business-as-usual prior to restoration. Seeking to value the action of restoring forested wetlands on cropland, we capture this economic value by calculating the difference in the values of ecosystem services provided by the two respective land use types.

\subsection{Biophysical Measurement of Ecosystem Service Flows}

Scientists at the USGS National Wetlands Research Center carried out the data collection for this study as part of the wetlands component of Conservation Effects Assessment Project's (CEAP) National Assessment (Faulkner et al., 2008). Initiated in 2003, CEAP is a multi-agency effort to evaluate the effectiveness of conservation practices used by private landowners participating in selected USDA conservation programs (Duriancik et al., 2008). The wetlands component of the National Assessment measures the effects of conservation practices on ecosystem services provided by wetlands in agricultural landscapes and is being conducted in eleven regions throughout the coterminous U.S. These regional assessments will focus on one or more wetland hydrogeomorphic classes common to agricultural land in that region.

For the CEAP-Wetlands study in the MAV, a stratified random sampling design was used in the Lower White-Cache (AR) and Tensas (LA) river basins where eight replicate sites were selected for each of three treatments: restored to forested wetlands under the WRP, active cropland, and natural forested wetland. These sites are representative 


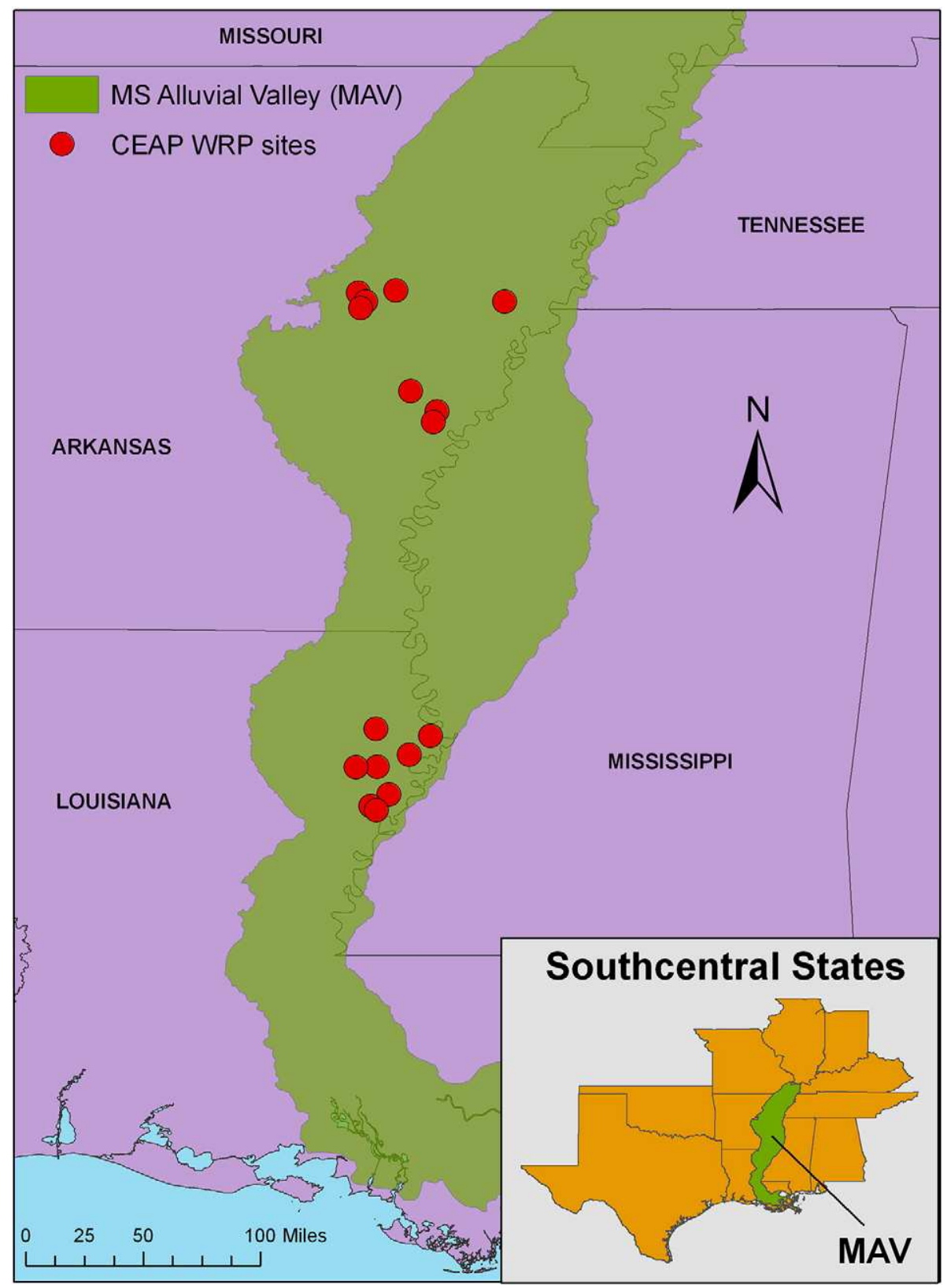

Fig. 1. Extent of the Mississippi Alluvial Valley (MAV) and the locations of the 16 WRP sites sampled by USGS scientists.

of the variability on the landscape and add up to 48 sites in total, 16 each of cropland, WRP, and natural forest. Site-level field data were collected in 2006 and 2007 for the following ecosystem services: carbon sequestration, nutrient retention, sediment retention, and amphibian and neotropical migrant bird species richness. In addition, a region-level assessment of waterfowl habitat was performed (for more detail, see Murray et al., 2009).

\section{Ecosystem Service Valuation: Methods and Results}

\subsection{Greenhouse Gas (GHG) Mitigation}

Converting land from croplands to forested wetlands can affect the GHG balance in the atmosphere in several ways. First, carbon dioxide $\left(\mathrm{CO}_{2}\right)$, the most prevalent $\mathrm{GHG}$, is removed from the atmosphere via photosynthesis and is sequestered in forest biomass and soils at levels typically well above the sequestration rate for crop systems. This creates a net carbon sink and reduces GHG concentrations, all else being equal.
Second, crop production can be a significant source of non- $\mathrm{CO}_{2}$ trace GHGs such as nitrous oxide $\left(\mathrm{N}_{2} \mathrm{O}\right)$ and methane $\left(\mathrm{CH}_{4}\right)$, gases that are individually more potent than $\mathrm{CO}_{2}$. Thus, discontinuation of agricultural practices reduces these emissions from the site. However, the anaerobic conditions of wetlands are ideal for the creation of methane and nitrous oxide and thus conversion can increase emissions accordingly. The net balance is determined by site conditions, as discussed below. Following that is the description of the process of converting GHG biophysical measures to monetary values.

\subsubsection{Carbon Sequestration}

The biophysical data collected by the CEAP research team for this service are point estimates of aboveground and soil carbon in metric tons of carbon per hectare in the first few years after restoration. Because carbon accumulation in ecosystems is a dynamic process, these point estimate snapshots need to be transformed into GHG flux over time in order to be properly monetized. Carbon accumulation growth is tracked in three carbon pools-soil, live biomass, and other 
non-soil-and is projected for the future employing two different process models.

3.1.1.1. Soil and Other Carbon. For soil carbon sequestration, we average the soil carbon point estimates collected through CEAP to create mean carbon values for all sites in the crop and WRP land use classes. Site soil carbon data are provided for the upper $15 \mathrm{~cm}$ of soil, where soil carbon is highest before decreasing dramatically with depth. These data are a reasonable proxy for $1 \mathrm{~m}$ of soil depth, the standard used in soil carbon estimation. Next, we seed the WRP mean values, $20.83 \mathrm{Mg}^{1} \mathrm{C} / \mathrm{ha}$ /year for Arkansas and 24.07 for Louisiana, into stand-level tables developed by the U.S. Forest Service as part of the federal 1605(b) GHG registry process. These tables are derived from the FORCARB2 forest carbon projection model and contain data on carbon accumulation growth paths for afforested and reforested stands in 5-year increments by carbon pool, forest type, and U.S. region (Smith et al., 2006). To use the FORCARB2 soil model, WRP land in the MAV is proxied by afforested oak-gum-cypress forest in the south-central U.S. The growth paths are traced out in 5-year time steps for 90 years from the initial year of restoration. Soil organic carbon at WRP sites is assumed to follow the same growth path as reported in the FORCARB2 lookup tables, though the beginning value is that provided by the CEAP field data.

At the agricultural sites, the initial soil carbon values come directly from the agricultural sites paired with the WRP sites in Arkansas and Louisiana. Conventional tillage is the assumed agricultural practice. In contrast to the WRP sites, agricultural soil carbon levels tend to gradually decrease over time as carbon is oxidized and released into the atmosphere as a result of crop production (Potter et al., 2006a). A 2006 NRCS study simulates the change in soil carbon content for agricultural lands over a 30-year time period with the Environmental Policy Integrated Climate (EPIC) model (Williams et al., 1989; Potter et al., 2006b). The analysis provides soil organic carbon estimates, as well as those for soil and nutrient losses, by region and by crop type.

MAV-specific estimates for other carbon found in standing dead, understory, and forest floor (i.e., not found in live trees) are currently unavailable, so we utilize the USFS FORCARB2 tables as the best available source. Growth in carbon in those pools is projected in the same way as described above for the WRP soil organic carbon.

3.1.1.2. Live Biomass Carbon. Live biomass carbon represents carbon stored in trees, both aboveground (i.e., trunks and branches) and belowground (i.e., coarse roots). Across the WRP sites, which had been planted between 4 and 12 years prior to sampling, live biomass carbon measurements average $2.70 \mathrm{Mg} / \mathrm{ha}$ in Arkansas (1.69-6.33 Mg/ha range) and $3.06 \mathrm{Mg} / \mathrm{ha}$ in Louisiana (1.79-5.71 Mg/ha range).

Of the carbon pools, the majority of carbon sequestration potential resides in the growth of live biomass carbon through time, increasing from $72 \%$ at year 10 to over $86 \%$ in year 90 according to the USFS FORCARB2 tables (Smith et al., 2006). We estimate the carbon accumulation flows of this pool using the growth function from Shoch et al. (2009), who examined the carbon sequestration potential of bottomland hardwood afforestation in the MAV. The authors produced a chronosequence of even-aged plantations and naturally regenerated stands and statistically estimated a growth path that is markedly greater for years 20 to 90 than that derived from the USFS FORCARB2 tables for afforested oak-gum-cypress stands (Smith et al., 2006).

This substantial difference between Shoch et al. (2009) and FORCARB2 is neither surprising nor a criticism of the FORCARB2, which is clearly defined as a model with large regional resolution. The

\footnotetext{
1 The abbreviation $M g$ stands for megagram; $1 \mathrm{Mg}$ is equivalent to 1 metric ton or $10^{6} \mathrm{~g}$. This paper uses $\mathrm{Mg}$ except in the context of the carbon credit trading market, in which the standard abbreviation $\mathrm{tCO}_{2} \mathrm{e}$ is used to refer to "metric tons of $\mathrm{CO}_{2}$ equivalent."
}

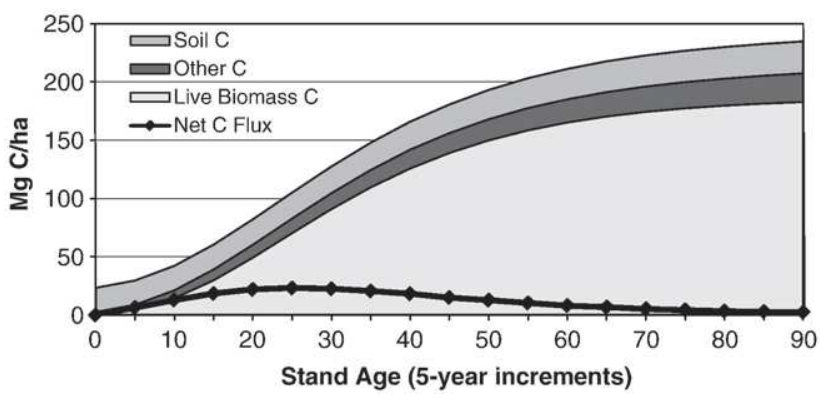

Fig. 2. Carbon growth and net carbon flux curves for afforested bottomland hardwood on WRP sites in Mississippi Alluvial Valley.

estimated growth curve from Shoch et al. is specific to the MAV and is thus more apt for our study than the FORCARB2 tables, whose estimates are for the south-central region in general. Dominated by bottomland red oaks, stem plantings in the WRP sites are very similar in species composition to the plantations surveyed by Shoch et al., further validating the use of their growth function. The CEAP field data for live biomass carbon falls approximately within the 95\% confidence interval of and well within the prediction interval of the total live tree biomass carbon growth curve generated by Shoch et al. Therefore, it is appropriate to project future live tree carbon accumulation for the WRP sites with the Shoch et al. growth function.

In Fig. 2, the carbon accumulation curve is depicted, with each major carbon pool represented by a different colored area. Carbon flux ( $\mathrm{MgC} / \mathrm{ha}$ /time period) is the net change of carbon on the site from one period to the next so that positive carbon flux represents new carbon stored in addition to the existing carbon stock. This is the service flow of interest as it directly relates to the removal of $\mathrm{CO}_{2}$ from the atmosphere, which provides the climate stabilization benefit. Flux often varies through time following the growth rate of the vegetation and soil carbon storage. The projected carbon flux for the WRP sites is represented by the dark line with diamonds in Fig. 2. Agricultural sites (not shown here) have a slightly negative carbon flux, since soil carbon declines gradually from soil oxidation associated with crop production (Potter et al.2006a) and the majority of crop biomass grown each year is removed from the land. Once the carbon fluxes for total site carbon have been calculated for the agriculture and WRP sites, we then convert them into units of carbon dioxide equivalents $\left(\mathrm{CO}_{2} \mathrm{e}\right)$ by multiplying by 3.67 , carbon's global warming potential (GWP). $\mathrm{CO}_{2} \mathrm{e}$ is the currency in which carbon service flows are monetized.

\subsubsection{Non- $\mathrm{CO}_{2}$ GHG Emissions}

The last step in quantifying the GHG sequestration potential is to account for the effect of emissions of trace GHGs, methane $\left(\mathrm{CH}_{4}\right)$ and nitrous oxide $\left(\mathrm{N}_{2} \mathrm{O}\right)$. They have GWPs much greater than $\mathrm{CO}_{2}$ itself: 25 for $\mathrm{CH}_{4}$ and 298 for $\mathrm{N}_{2} \mathrm{O}$ for a 100 -year time horizon (IPCC, 2007). Both crop and wetland sites are net sources of $\mathrm{CH}_{4}$ and $\mathrm{N}_{2} \mathrm{O}$ emissions, though of different magnitudes. Accordingly, site $\mathrm{N}_{2} \mathrm{O}$ and $\mathrm{CH}_{4}$ fluxes are converted to their $\mathrm{CO}_{2}$ equivalents using their GWPs and are then deducted from the $\mathrm{CO}_{2}$ flux to determine the net GHG flux $\left(\mathrm{MgCO}_{2} \mathrm{e} /\right.$ ha/year). ${ }^{2}$

For the agricultural sites in the region, $\mathrm{CH}_{4}$ is emitted through rice production and residue burning and $\mathrm{N}_{2} \mathrm{O}$ is emitted through the use of nitrogenous fertilizers and nitrogen fixation by soybeans. To find these GHG fluxes, we first determine the crop mixes for a representative agricultural hectare in the MAV for each state using data compiled by

\footnotetext{
2 We depart from convention on the sign of the flux. We use the terrestrial ecosystem itself as the stock from which fluxes occur. Thus, a negative flux is an emission (e.g., the release of $\mathrm{N}_{2} \mathrm{O}$ from denitrification), whereas carbon sequestration is a positive flux (e.g., carbon captured through tree growth). We do this to highlight the notion that a positive number (increased sequestration or reduced emissions) is "mitigation" representing an environmental benefit that can receive a positive payment as discussed throughout.
} 
USDA National Agricultural Statistics Service (USDA-NASS, 2009). Then, we multiply the crop mixes by the corresponding state average estimates for agricultural $\mathrm{CH}_{4}$ and $\mathrm{N}_{2} \mathrm{O}$ emissions from the FASOMGHG model (Adams et al., 2005). Finally, weighted averages for the three MAV states are produced: $-6.00 \mathrm{MgCO}_{2} \mathrm{e} / \mathrm{ha} / 5$ years for $\mathrm{CH}_{4}$ and $-3.17 \mathrm{MgCO}_{2} \mathrm{e} / \mathrm{ha} / 5$ years for $\mathrm{N}_{2} \mathrm{O}$.

For both WRP and natural wetland sites, the levels of $\mathrm{CH}_{4}$ and $\mathrm{N}_{2} \mathrm{O}$ emissions vary by landscape position, i.e., whether the site is located in a low- or high-elevation position. Low-elevation sites flood more frequently and for longer duration than high-elevation sites and thus will experience longer periods with anoxic conditions in the soil. This anoxia is a prerequisite for the processes of methanogenesis and denitrification to produce gaseous methane and convert nitrate into gaseous dinitrogen $\left(\mathrm{N}_{2}\right)$ and nitrous oxide $\left(\mathrm{N}_{2} \mathrm{O}\right)$ (Mitsch and Gosselink, 2007). Since a goal of WRP is to remove frequently flooded, marginal croplands from commodity crop production, we estimate that approximately $80 \%$ of the WRP area is characterized as low elevation and the other $20 \%$ as high elevation. We multiply the $\mathrm{CH}_{4}$ and $\mathrm{N}_{2} \mathrm{O}$ emission rates for each landscape position by the corresponding proportion (0.8/0.2) and generate a weighted average of $\mathrm{CH}_{4}$ and $\mathrm{N}_{2} \mathrm{O}$ emissions for each 5 -year increment between years 5 and 90 after the wetlands restoration. After converting to $\mathrm{MgCO}_{2}$ equivalents, the mean $\mathrm{CH}_{4}$ flux is $-0.13 \mathrm{MgCO}_{2} \mathrm{e} / \mathrm{ha} / 5$ years and the mean $\mathrm{N}_{2} \mathrm{O}$ flux $-2.02 \mathrm{Mg} \mathrm{O}_{2} \mathrm{e} / \mathrm{ha} / 5$ years.

\subsubsection{Total GHG Flux Change}

Since a typical agricultural site candidate for restoration serves as the baseline, full GHG flux for restoring an hectare of wetland is the difference between the GHG fluxes for the average MAV agricultural sites and WRP sites. Fig. 3 shows these three flux streams over the 90 -year study period. Agricultural sites function as sources of GHG emissions and have a negative flux value for mitigation purposes (see footnote 2 ). In contrast, WRP sites serve as net sinks, have a positive mitigation flux value, and sequester up to $82.2 \mathrm{Mg}$ of new $\mathrm{CO}_{2}$ per hectare per 5-year period. Although non- $\mathrm{CO}_{2} \mathrm{GHG}$ gases are emitted in restored wetlands, their contribution is easily offset and exceeded by the carbon sequestration of the growing wetland forests. The net GHG mitigation value of restoring wetlands ranges between 15.8 and $92.4 \mathrm{MgCO}_{2} \mathrm{e} / \mathrm{ha} / 5$ years, with the peak coming at 25 years after planting the tree seedlings.

\subsubsection{Monetizing GHG Mitigation}

The social welfare value of GHG mitigation captures the value of the damages avoided by mitigating the risks of climate change. This is typically estimated with the use of integrated assessment general equilibrium models to capture the social cost of carbon, or SCC. The IPCC Fourth Assessment Report (2007) reviews studies in the environmental economics literature that investigated the benefits of GHG mitigation and finds that mean estimates for SCC range from about $\$ 13 / \mathrm{MgCO}_{2}$ to $\$ 17 / \mathrm{MgCO}_{2}$ in 2008 US\$. We use this range as the shadow prices for $1 \mathrm{Mg}$ of GHG mitigated on our study sites.

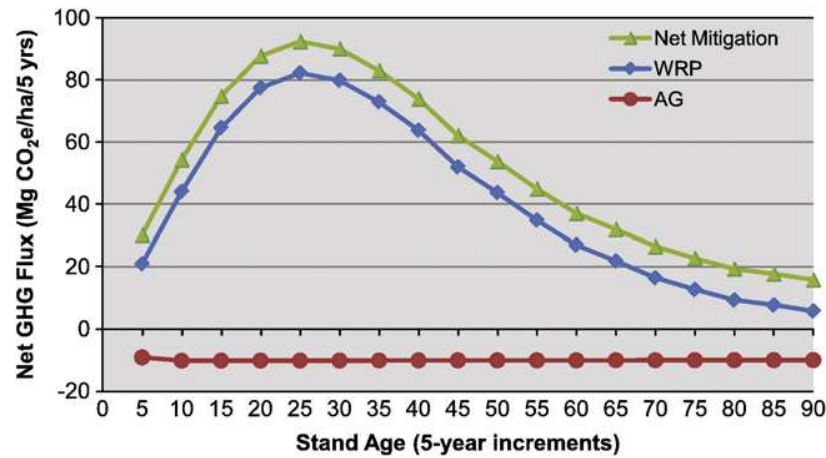

Fig. 3. Net greenhouse gas (GHG) mitigation from converting agricultural sites (AG) to WRP sites.
The stream of total GHG flux per hectare is multiplied by the market and social value prices and then discounted back to the present with a $4 \%$ real discount rate. The present value of the GHG mitigation service is divided by the 90 -year annuity factor to yield the annualized values per hectare that appear in Fig. 4. The monetized net mitigation value is the difference between the WRP and agriculture sites, ranging from $\$ 171$ to $\$ 222 /$ ha/year for the social values.

\subsection{Nitrogen Mitigation}

\subsubsection{Quantifying Nitrogen Service Flows}

Nitrogen is a major nutrient in agricultural runoff strongly linked to water quality degradation, such as eutrophication (Carpenter et al., 1998). In particular, increase in nitrogen loading to the Mississippi River is considered a principal cause of the hypoxic "dead zone" in the Gulf of Mexico (Goolsby and Battaglin, 2001). There are two principal ways in which wetlands restoration mitigates environmental damage from nitrogen releases: (1) forgone nitrogen $(\mathrm{N})$ losses associated with runoff from crop cultivation and $(2)$ removal of nitrate $\left(\mathrm{NO}_{3}\right)$ via denitrification.

When land is enrolled in a WRP easement, it is by definition taken out of agricultural production and thus the $\mathrm{N}$ losses driven by fertilizer application, fixation, and tilling cease. Because nitrate is the species of $\mathrm{N}$ most clearly correlated with the hypoxic zone size in the Gulf of Mexico, we focus on nitrate loading in our analysis (Mississippi River/ Gulf of Mexico Water Nutrient Task Force, 2007). We compute the nitrate prevented from entering the local waterways by applying average annual values for nitrate lost in surface-water runoff, in lateral subsurface flow, and in leachate $(\mathrm{N} \mathrm{kg} / \mathrm{ha} / \mathrm{year})$ from agricultural sites using output from the EPIC model (Potter et al. 2006b). These EPIC model estimates are available by U.S. region and by primary crop type within each region (Potter et al. 2006a). Knowing the counties in which the paired WRP and reference agricultural sites are located in the MAV but not their exact location due to privacy restrictions, we create representative crop sites for the MAV portion of each state with USDA data that details the crop mix for those counties (USDA-NASS, 2009). The nitrate loss estimates for each crop type are combined with the crop type proportions to produce total nitrate loss for a representative agricultural hectare in the MAV in that state. See Table 1 for an example calculation for Arkansas. Total nitrate ground- and surface-water losses for the MAV counties in Arkansas, Louisiana, and Mississippi are 39.9, 31.3, and $32.2 \mathrm{~kg} / \mathrm{ha} /$ year, respectively. Computed using the relative total hectares planted in crops in the MAV counties for each state, the weighted average of agriculture-related nitrate loss for the MAV is $36.2 \mathrm{~kg} / \mathrm{ha} / \mathrm{year}$.

The second mitigation pathway is the removal of nitrate through the denitrification process, which is the primary $\mathrm{N}$ loss process in freshwater wetland ecosystems (Faulkner and Richardson, 1989; Mitsch et al., 2001). The complex interactions of hydrology, soil type,

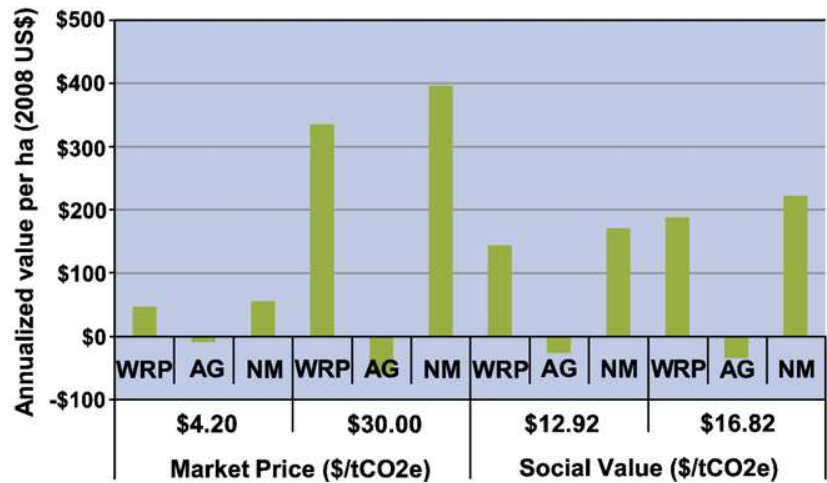

Fig. 4. Annualized value per hectare in 2008 US\$ for WRP, agricultural sites (AG), and net mitigation (NM) under market and social value prices for $1 \mathrm{MgCO}_{2} \mathrm{e}$. 
Table 1

Estimated annual nitrate loss by crop type from a representative agricultural hectare in the MAV in Arkansas.

\begin{tabular}{lllc}
\hline Crop type & $\begin{array}{l}\text { Estimated } \mathrm{NO}_{3} \text { loss } \\
(\mathrm{kg} / \mathrm{ha} / \text { year })\end{array}$ & Crop proportion & $\begin{array}{l}\text { Crop contribution } \\
(\mathrm{kg} / \mathrm{ha} / \text { year })\end{array}$ \\
\hline Corn & 24.9 & 0.03 & 0.75 \\
Cotton & 29.4 & 0.18 & 5.34 \\
Rice & 69.9 & 0.28 & 19.92 \\
Sorghum & 13.1 & 0.01 & 0.08 \\
Soy & 29.0 & 0.47 & 13.64 \\
Wheat & 5.7 & 0.03 & 0.16 \\
& & Total & 39.89 \\
\hline
\end{tabular}

nutrient loadings, and landscape position create the variability in specific ecosystem processes found in natural wetlands (even within a wetland type) and there is a wide range in reported nutrient retention rates due to differences in specific processes controlling those rates (Faulkner and Richardson, 1989; Reddy et al., 1999; Novak et al., 2004; Lowrance et al., 2006). Reported denitrification rates in natural forested wetlands range from $<1$ to $>800 \mathrm{~kg} \mathrm{~N} / \mathrm{ha} /$ year (Mitsch et al., 2001; Lowrance et al., 2006). In addition, there is evidence that restored forested wetlands have rates that change as the system ages and develops ecosystem characteristics more similar to forests than croplands (Hunter and Faulkner, 2001; Ullah and Faulkner, 2006a). This variability makes it difficult to predict $\mathrm{N}$ retention rates for WRP sites through time. Denitrification potential $\left(\mathrm{kg} \mathrm{NO}_{3} /\right.$ ha/year) was estimated with the denitrification enzyme assay (DEA) using field soil samples from both cropland and WRP CEAP sites. This denitrification potential approximates the rate at which nitrate is removed from the site. The DEA is a widely used approach (Groffman and Tiedje, 1989; Clement et al., 2002; Ullah and Faulkner, 2006a). We also reviewed published denitrification rates and found several studies that were similar to the WRP and natural sites evaluated here (Peterjohn and Correll, 1984; Lowrance et al., 1984; Mitsch et al., 2001; Ullah and Faulkner, 2006a,b).

In order to capture the future denitrification potential of the restored wetlands, we modeled the relationship between the ages of forested wetland stands and the denitrification rates using the CEAP WRP data; unpublished data from sites at Red River, Louisiana; and six point estimates from the literature. As can be seen in Fig. 5, a log function fits the data well with a $R^{2}$ value of 0.7183 . We use this curve to represent the age-dependent trajectory of denitrification through the 90 -year study period at sites with a low landscape position. Since none of the published denitrification rates distinguish between lowand high-elevation sites in forested wetlands, we used experimental data which indicates that high-elevation sites display denitrification rates that are about $10 \%$ of those of low-elevation sites-low $28.8 \mathrm{~kg} \mathrm{~N} /$ ha/year vs. high $2.88 \mathrm{~kg} \mathrm{~N} / \mathrm{ha} /$ year (Faulkner, unpublished data). Therefore, we assume that denitrification rates at high-elevation sites have the same trajectory as those at low-elevation sites, but with one-tenth of the value. Applying our assumption that $80 \%$ of the area of the WRP sites is low elevation and $20 \%$ is high elevation, we add together the proportional contribution of each site type to yield the combined nitrate mitigated each year via the denitrification process. ${ }^{3}$

Nitrogen losses from agricultural land are a nitrogen source to the waterway, i.e., they have a negative mitigation value, while denitrification is considered a nitrogen sink, keeping $\mathrm{N}$ from entering the waterway and generating a positive mitigation benefit. Since restoring a wetland on cropland precludes additional agriculture-related nitrate losses, those forgone losses are then seen as a positive mitigation value. We assume that forgone nitrate losses from crop production

\footnotetext{
${ }^{3}$ We assume that the sampling mix of bottomland forest stands used in the Shoch et al. (2009) analysis that provides the carbon accumulation curve for the projected live biomass of afforested WRP sites in the present study (see Section 3.1.1.2) is consistent with this $80 \%$ low $/ 20 \%$ high distribution.
}

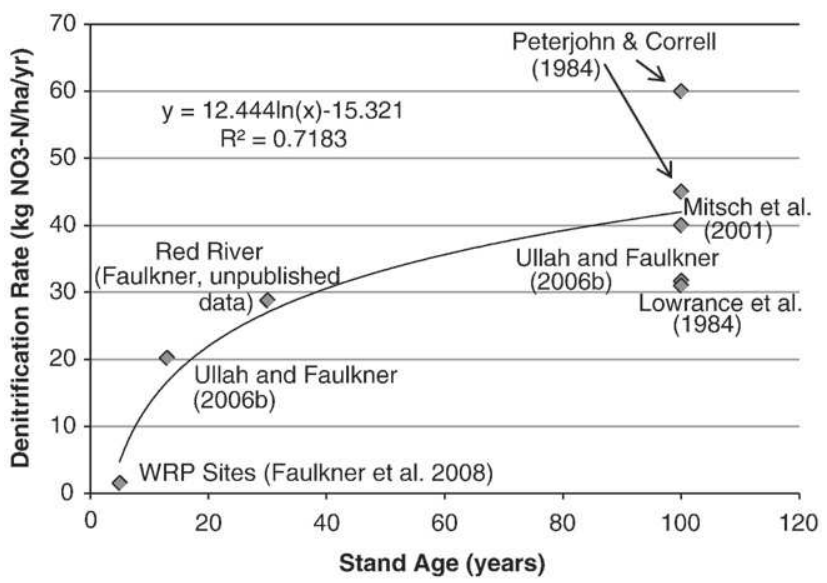

Fig. 5. Log function fitted between measured denitrification rate and stand age of forested wetlands.

remain constant through the study period so that annual nitrate mitigated equals the forgone nitrate losses (36.2 kg N/ha/year) plus the current level of denitrification. Because the agricultural site functions as the baseline, the nitrogen eliminated through denitrification there must be netted out to arrive at the nitrate mitigated due to WRP wetlands restoration. It is assumed that the denitrification rate on cropland does not "mature" through time and so the constant mean value for the 16 CEAP agricultural sites, $1.69 \mathrm{~kg} \mathrm{~N} / \mathrm{ha} / \mathrm{year}$, is subtracted annually.

Fig. 6 depicts the curves of denitrification rates for WRP low, high, weighted average, as well as for agricultural sites; the nitrate losses associated with crop production; and the total nitrate mitigated. Total nitrate abatement is dominated by the cropland $\mathrm{N}$ loss pathway in the years immediately after a wetland restoration takes place. As the wetland grows, the contribution of denitrification to total nitrate mitigated rises from $10 \%$ at year 5 to nearly $50 \%$ by year 90 . Total nitrate mitigated increases from about $36 \mathrm{~kg} \mathrm{~N} / \mathrm{ha} / \mathrm{yr}$ in the early years to almost $68 \mathrm{~kg} \mathrm{~N} / \mathrm{ha} / \mathrm{year}$ by the end of the study period.

\subsubsection{Monetizing Nitrogen Mitigation}

Nitrogen mitigation is monetized using a price estimated for the Delta region (Arkansas, Louisiana, and Mississippi) of the U.S. South in Ribaudo et al. (2005). That study's results are selected for the benefit transfer because it is one of the few studies in the literature that produces a marginal price for nitrogen mitigation; moreover, its estimates are also specific to the MAV study area. Ribaudo et al. (2005) employ the U.S. Agricultural Sector Mathematical Programming (USMP) model to explore the potential for nitrogen credit trading in the entire Mississippi Basin by modeling the interaction

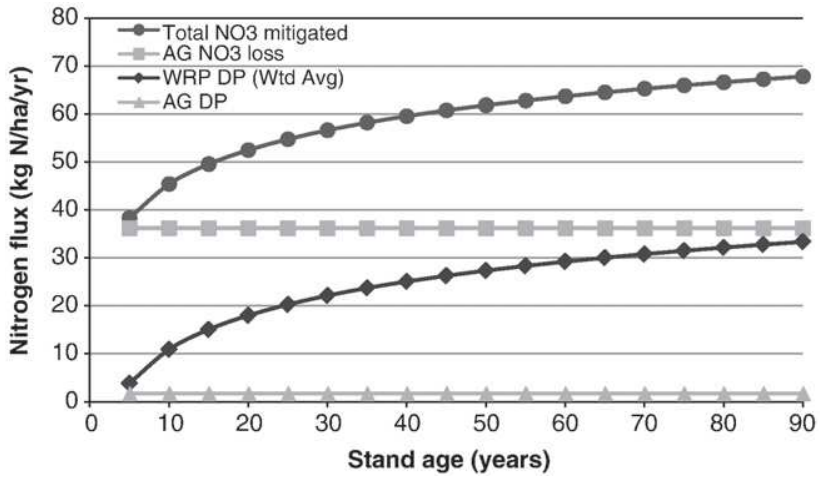

Fig. 6. Nitrogen (N) flux accounting for MAV counties over the 90 -year study period. DP is denitrification potential, WRP is the WRP sites, and AG is the agricultural sites. Wtd Avg is $80 \%$ low elevation, $20 \%$ high elevation. 
Table 2

Annualized value of $\mathrm{N}$ mitigation service and range of values depending on costs of marginal N credits in Ribaudo et al. (2005) (all values in 2008 US\$).

\begin{tabular}{llll}
\hline & $\begin{array}{l}\text { Cost of marginal N credit } \\
(\$ / \mathrm{kg} \mathrm{N})\end{array}$ & Net present value & $\begin{array}{l}\text { Annualized value } \\
(\$ / \text { ha/year })\end{array}$ \\
\hline Study area & $\$ 25.27$ & $\$ 30,286.62$ & $\$ 1248.04$ \\
Lower bound & $\$ 22.82$ & $\$ 27,350.24$ & $\$ 1127.04$ \\
Upper bound & $\$ 106.09$ & $\$ 127,151.06$ & $\$ 5239.61$ \\
\hline
\end{tabular}

between agricultural nonpoint sources and wastewater treatment plant point sources mandated to reduce nitrogen emissions. In the model, farmers are able to provide nitrogen reduction credits via the following four methods: changing fertilizer application rates, changing production practices, growing different crops, or retiring cropland. Restoring wetlands is not included as a mitigation option because, in an earlier paper, Ribaudo et al. (2001) demonstrated that wetlands restoration is generally more expensive than fertilizer management and therefore a less attractive alternative for farmers. However, the cost of the alternative approaches does capture the avoided costs of achieving the given level of water quality improvements in another way when wetlands restoration is undertaken in the region, and thus provides a workable marginal value for wetland $\mathrm{N}$ mitigation outcomes. ${ }^{4}$

The cost of the marginal trade for the Delta region is estimated at $\$ 10.50 / \mathrm{lb} \mathrm{N}$, a result which we transform to $\$ 25.27 / \mathrm{kg}$ N by converting it to price per kilogram and then by inflating the price to 2008 dollars using the CPI Inflation Calculator (BLS, 2009). ${ }^{5}$ For the dynamic model of nitrogen mitigation developed here, the monetization step follows the same process as applied to the GHG mitigation service. Each year the amount of total nitrogen abated is multiplied by $\$ 25.27 / \mathrm{kg} \mathrm{N}$. Next, the 90 -year stream of $\mathrm{N}$ mitigation values are discounted back to the present using a $4 \%$ discount rate and then converted to an annualized value. The result is $\$ 1248 /$ ha/year. A range of values for $\mathrm{N}$ mitigation is derived by using the lowest and highest $\mathrm{N}$ credit prices among all subregions in the Mississippi Basin generated by Ribaudo et al. (2005). In Table 2, the costs of a marginal N credit range from $\$ 22.82$ to $\$ 106.09$ / $\mathrm{kg} \mathrm{N}$ and the interval of annualized values is between $\$ 1127$ and $\$ 5240$. The costs to mitigate nitrogen in the MAV are clearly at the low end of the range and may therefore represent a relatively conservative estimate for the valuation of nitrogen mitigation service. ${ }^{6}$

\subsection{Social Value of Ecosystem Services: Partial Estimate}

To generate a partial estimate for the ecosystem value of wetlands restoration, we combine the social value for waterfowl recreation with the results from the preceding two ecosystem services valuation applications (see Table 3). Regarding waterfowl recreation, when cropland is restored to wetlands, this means an increase in waterfowl habitat, which in turn implies augmented hunting opportunities for recreationists. Waterfowl hunter days were assumed to grow as habitat expands and we multiply the change in number of hunting days by a perday consumer surplus value taken from a meta-analytical study on outdoor recreation values conducted for the U.S. Forest Service (Rosenberger and Loomis, 2001). This is worth $\$ 16 /$ ha/year to waterfowl

\footnotetext{
${ }^{4}$ We recognize that replacement cost is conceptually a less-preferred shadow price than a directly estimated WTP value for the service, but unfortunately there are no direct estimates of WTP to draw from. We do believe replacement cost is an empirically valid measure for the region because policies are attempting to take a suite of approaches to achieving certain water quality targets for the region (Mississipp River/Gulf of Mexico Water Nutrient Task Force, 2007).

${ }^{5}$ As a comparison, the Nutrient Offset Program run by North Carolina's Ecosystem Enhancement Program uses \$21.67/lb N for the Tar-Pamlico River Basin and \$28.35/lb $\mathrm{N}$ in the Neuse Basin $(\$ 47.77 / \mathrm{kg} \mathrm{N}$ and $\$ 62.50 / \mathrm{kg} \mathrm{N}$ ) for offset payments to mitigate nitrogen (http://www.nceep.net/services/stratplan/Nutrient_Offset_Program.htm).

${ }^{6}$ One reviewer commented that these values do not account for the potential benefits that downstream farmers may derive from heightened nitrogen levels in their irrigation water.
}

Table 3

Benefit estimates of individual ecosystem services for social welfare value, and market value, assuming current markets or potential markets (estimates in $\$ 2008 / \mathrm{ha} /$ year).

\begin{tabular}{llll}
\hline Ecosystem service & Social value & $\begin{array}{l}\text { Market value }- \\
\text { current markets }\end{array}$ & $\begin{array}{l}\text { Market value - } \\
\text { potential markets }\end{array}$ \\
\hline GHG mitigation & $\$ 171-\$ 222$ & $\$ 55$ & $\$ 396$ \\
Nitrogen mitigation & $\$ 1248$ & $\$ 0$ & $\$ 624$ \\
Waterfowl recreation & $\$ 16$ & $\$ 15$ & $\$ 15$ \\
Total & $\$ 1435-\$ 1486$ & $\$ 70$ & $\$ 1035$ \\
\hline
\end{tabular}

hunters (methods detailed in Murray et al., 2009). Although they were not monetized in this analysis, it can be assumed that floodwater storage, sediment retention, and other wildlife habitat services also possess positive economic values. Therefore, the social value estimated here, which ranges from $\$ 1435$ to $\$ 1486 /$ ha/year, is necessarily a lower bound on the full social value of restoring wetlands.

\subsection{Market Value}

The estimates in the section above are measures of social welfare value and are thus appropriate to use for social benefit-cost analysis to gauge the performance of public programs such as WRP. However, the emergence of ecosystem service markets raises the question of whether private markets can play a role in incentivizing socially beneficial landowner behavior. Thus, we turn to an assessment of market value with the potential to be captured by landowners in the region. ${ }^{7}$

\subsubsection{GHG Mitigation}

Market value for GHG mitigation is realized through the existence of carbon markets for GHG mitigation, wherein landowners can be compensated for sequestering carbon or reducing emissions below a baseline as part of an offset program in a cap-and-trade system. In 2008 , carbon credits were traded as an environmental commodity on the voluntary Chicago Climate Exchange in the range of $\$ 1.00$ and $\$ 7.40 / \mathrm{CCO}_{2} \mathrm{e}$ (Chicago Climate Exchange, 2009). We use the midpoint of this range, $\$ 4.20 / \mathrm{tCO}_{2} \mathrm{e}$, for the low market price in the analysis. Because voluntary demand is generally less binding than a mandatory system, this price is relatively low. Prices on the European Union Emissions Trading Scheme (EU ETS), part of the Kyoto Protocol compliance driven market have been much higher, near $\$ 35 / t \mathrm{CO}_{2} \mathrm{e}$ in the summer of 2008, but we do not use this value because the ETS does not allow forest carbon in its trading. Instead, we draw upon the analysis of the recently proposed Lieberman-Warner climate change bill (S. 2191), which calls for a federal cap-and-trade program covering the energy, transportation, and industrial sectors with mitigation from the forest sector usable as offset credits for the capped sectors (US EPA, 2008). This analysis yielded carbon price estimates of about $\$ 20$ to $\$ 30 / \mathrm{tCO}_{2} \mathrm{e}$. We use $\$ 30 / \mathrm{t} \mathrm{CO} 2 \mathrm{e}$ as the upper end of the market price range. In Table 3 , annualized values per hectare for GHG mitigation are calculated to be about $\$ 55$ for the low market price and over $\$ 396$ for the high market price.

GHG offset payments in forestry and agriculture are typically modified to account for permanence, additionality, and leakage (Murray et al., 2007). Permanence reflects the fact that stored carbon could be re-released due, for instance, to harvesting the timber after some time. Seeing that the majority of WRP easements in our study area are permanent, we assume that the converted wetlands will not be harvested and thus we make no adjustment for impermanence. Additionality adjusts for the fact that some of the activity getting credited may have happened anyway without the payment. This is

\footnotetext{
${ }^{7}$ The operative definition of baseline used in service quantification will depend on the standards of the particular ecosystem market. For simplicity, we use cropland as the baseline for both the social and market value estimates.
} 
unlikely in the case of hardwood restoration in the MAV, as afforestation rates are extremely low there without any kind of government inducement. So no further adjustment is made. Leakage means that GHG sequestration services gained in one area are partially compensated by loss in another. This can happen when restoring cropland to wetlands in one place could cause land clearing for agriculture in another. Leakage rates have been estimated at $43 \%$ for forest carbon sequestration programs in the south-central region (Murray et al., 2004). Nevertheless, although ecosystem service values determined here may be offset by leakage elsewhere of the system, perhaps by as much as $20 \%$ to $40 \%$, the direct estimation of that leakage effect is outside the scope of this study. Therefore, following the protocol used by the Chicago Climate Exchange for Afforestation Offset projects (Chicago Climate Exchange, 2007), we present the calculated GHG flux values (and all other ES values estimated here) without adjusting for leakage.

\subsubsection{Nitrogen Mitigation}

Although there are more than 40 nutrient trading programs on the books in the U.S., very few trades have taken place to date (Ribaudo et al., 2008). As such, the market value under existing markets is essentially zero for $\mathrm{N}$ mitigation. Nevertheless, given the substantial interest in nutrient trading and the degraded condition of many of the nation's waterways, it is not implausible that $\mathrm{N}$ abatement will gain a market value in the future. Note that the potential market value of the nitrogen mitigation service equals only half of the social value because we assume that a nutrient trading scheme would require a trading ratio of at least 2:1. The most common ratio for trading between point and nonpoint sources is 2:1 (Morgan and Wolverton, 2005). That is, $2 \mathrm{~kg}$ of nitrogen need to be mitigated by landowners for every $1 \mathrm{~kg}$ of nitrogen credit generated. Ratios are used in order to reduce the uncertainty involved with nutrient mitigation by nonpoint sources such as farms. Therefore, we estimate an annualized potential market value of $\$ 624 /$ ha/year for nitrogen mitigation.

\subsubsection{Market Value Summary}

In Table 3, ecosystem service market values are summarized along with the social value. As above, we include the waterfowl recreation value since WRP participants can be seen as producers of the waterfowl habitat and capture a portion of the created value through hunting leases. Using the mean of recent studies on hunting leases in Mississippi, the annual market value estimate for waterfowl recreation is about \$15/ha (Hussain et al., 2007; Rhyne and Munn, 2007).

Given current markets, the market value of ecosystem services is approximately $\$ 70 / \mathrm{ha} /$ year. This pales in comparison to the estimated social value of $\$ 1435$ to $\$ 1486 /$ ha/year; however, the gap closes to a large degree when one considers potential markets for ecosystem services. At $\$ 1035 /$ ha/year, the potential market value is about $70 \%$ of the social value and nearly 15 times the market value under existing markets. Nitrogen mitigation is clearly the driver for both of the larger values, comprising $60 \%$ of the potential market value and around $85 \%$ of the social value.

\section{Comparisons with Costs of Wetland Restoration}

To provide context for the above estimates of ecosystem service benefits, we examine the two types of costs related to their provision. The first is the private cost borne by the landowner and the second is the social cost of implementing WRP shouldered by the federal government. We do not attempt to conduct a full cost-benefit analysis, which would imply a complete accounting of all costs and benefits of wetlands restoration. For ease of comparison with the estimated benefits, costs are converted to per-hectare units.

\subsection{Landowner Perspective}

From the perspective of the MAV landowner, the main opportunity cost of wetland restoration is the forgone income from agricultural use of the land. We estimate this cost by considering the net returns from crop production for the three Delta states, which vary substantially by crop type and by year over the period of 1997 to 2005 (USDA ERS). Using the representative agricultural hectare approach described in Section 3.1.2, we find that the annual return for an hectare of crop production in the MAV is $\$ 309$.

Another relevant source of income for agricultural producers is government payment programs. The 2002 Farm Bill furnishes three types of payments to farmers, of which only the direct payment is provided annually and is independent of the crop cultivated (Ibendahl, 2004). The provision of the countercyclical and loan deficiency payments hinges on national and county crop prices and is not guaranteed each year. Focusing on the delta region of Mississippi, Anderson and Parkhurst (2004) calculated that the sums of the direct and maximum countercyclical payments per base hectare are $\$ 42$ for soybeans, $\$ 343$ for cotton, and $\$ 385$ for rice. Ibendahl (2008) finds that for three Mississippi counties, expected government payments for cotton and soybeans average $\$ 329$ and $\$ 62 /$ ha, respectively. Applying these values to the representative agricultural hectare approach, we obtain a conservative estimate of about $\$ 91 /$ ha.

Using $\$ 309$ as the value of an hectare for crop production and $\$ 91$ as the annual government payment subsidy, their sum of $\$ 400$ represents the estimated annual per-hectare income forgone by a private landowner who opts to enroll acreage in the WRP. Additionally, if the landowner wished to undertake a wetlands restoration on his property without enrolling in a conservation program, one-time costs for afforestation projects in the MAV may run around $\$ 680$ to $\$ 900 / \mathrm{ha}^{8}$ Assuming that those restoration costs are paid up front, a present value analysis combining foregone agricultural income with the restoration costs over a 30-year horizon yields an annualized value of $\$ 455$ to $\$ 468$. Currently the annual market value that could be captured from existing carbon and hunting markets amounts to $\$ 70 /$ ha, only about $18 \%$ of the net returns from agricultural production. In contrast, the potential market value of GHG mitigation, nitrogen mitigation, and wildlife habitat provision with emerging ecosystem markets is \$1035-over two times greater than the restoration opportunity costs. This shows that, without the payments provided by WRP, landowners will not have sufficient economic incentive to undertake wetlands restoration on their properties until markets for environmental services become more fully developed.

\subsection{Taxpayer Perspective}

The principal costs to taxpayers of restoring wetlands via the WRP are the easement payments to landowners and the cost share of the restoration. Easement payments provide compensation to the landowner for forgoing agriculture and are made as a lump sum in the first year of the WRP contract. Under a 30-year easement, the USDA pays up to $75 \%$ of the restoration cost, while it covers up to $100 \%$ of the cost for a permanent easement (USDA-NRCS, 2007). The third enrollment option is the restoration cost-share agreement that does not place an easement on the property and in which USDA pays up to $75 \%$ of restoration cost. The publically available cost data for the WRP aggregates the annual costs for all three contract options at the state level for 2003 to 2007 (USDA-NRCS, 2008). From this data, we can derive approximate per-hectare costs incurred by the USDA for each state. The 5-year average across the three Delta states is $\$ 2617 /$ ha in

\footnotetext{
${ }^{8}$ NRCS costs for restoring a forested wetland in Arkansas are approximately \$680/ha (personal communication, Andrew James 2009). A private firm specializing in afforestation projects may charge around \$865-\$926/ha for a carbon offsets package (personal communication, Carol Jordan 2009).
} 
Table 4

Annual GHG mitigation, nitrogen mitigation, and waterfowl recreation social values (2008 US\$) for WRP land aggregated at the MAV level.

\begin{tabular}{clllll}
\hline & $\begin{array}{l}\text { Extent } \\
\text { (ha) }\end{array}$ & $\begin{array}{l}\text { GHG } \\
\text { mitigation }\end{array}$ & N mitigation & $\begin{array}{l}\text { Waterfowl } \\
\text { recreation }\end{array}$ & $\begin{array}{l}\text { Aggregate } \\
\text { value }\end{array}$ \\
\hline $\begin{array}{c}\text { WRP per ha } \\
\text { (range) }\end{array}$ & & $\$ 193-\$ 366$ & $\$ 918-\$ 1896$ & $\$ 16$ & $\$ 1127-\$ 2278$ \\
All WRP land & 207,751 & $\$ 44,844,289$ & $\$ 249,088,722$ & $\$ 3322,896$ & $\$ 297,255,907$ \\
\hline
\end{tabular}

2008 dollars. Since the government is no longer obligated to provide agricultural payments when a farmer enrolls land in WRP, the 30-year discounted present value of the annual subsidy estimated above ( $\$ 91$ ) should be subtracted from the WRP cost. We use the remainder of $\$ 980 /$ ha as the public expenditure or social cost of wetlands restoration in the MAV.
Again considering the values reported in Table 3, it would only take 1 year for the social benefits of wetlands restoration ( $\sim 1450 / \mathrm{ha}$ / year) to surpass the costs incurred by the government in paying for the WRP. Furthermore, the estimated social benefits represent a lower bound on the total ecosystem value since several ecosystem services are not accounted for in the analysis.

\section{Benefit Aggregation for MAV}

The measurement of aggregate benefits resulting from a program can be useful to policymakers by providing an estimate of the magnitude of program impacts. Using the per-hectare values for the three focal ecosystem services, we can scale them up to generate aggregate values for the entire MAV. Examining the benefits associated with the land currently enrolled in WRP there, we observe that there are 207,751 ha in WRP easements in the 67 counties in the MAV (as of 2005). Note that four Mississippi counties are excluded

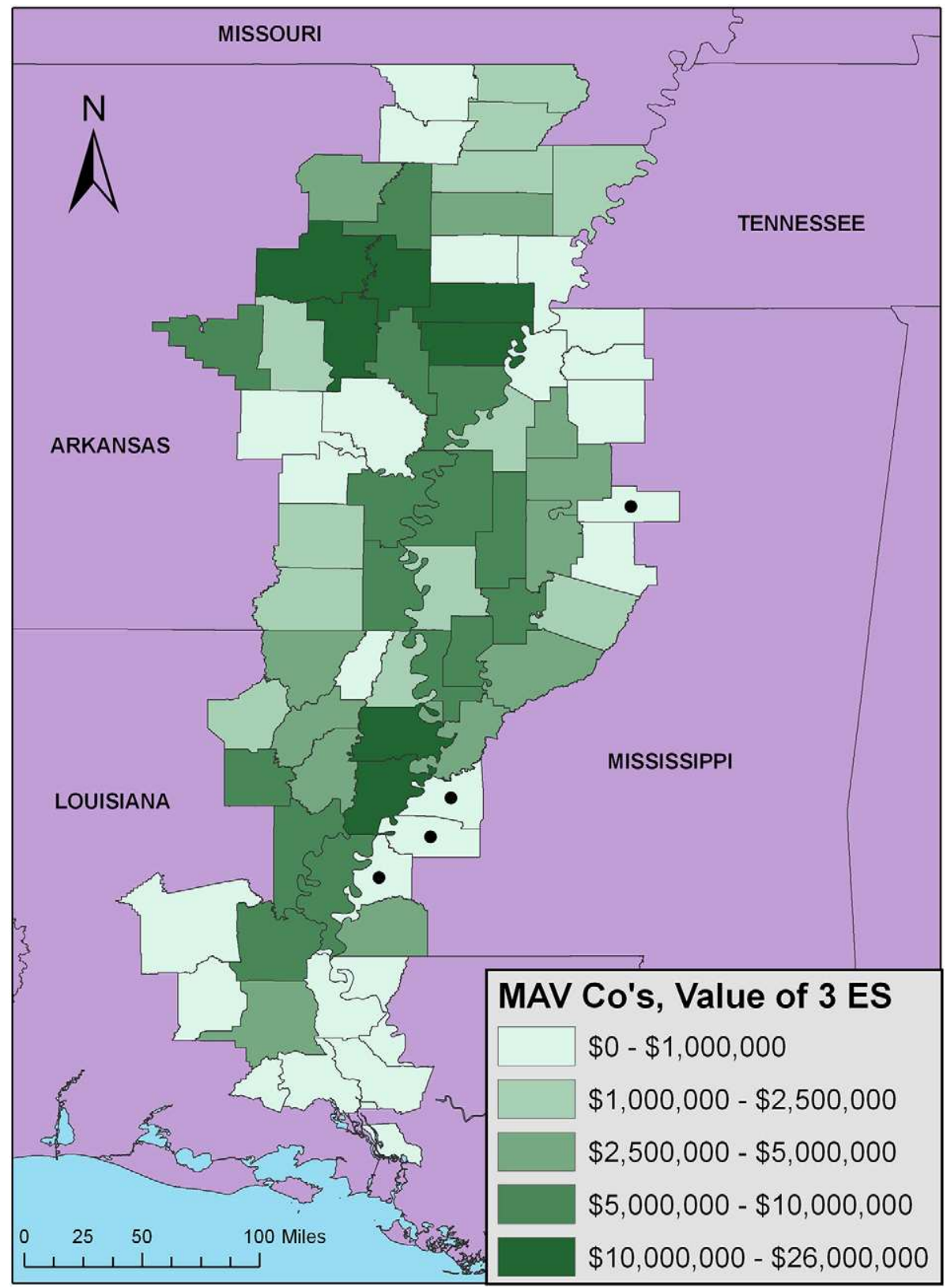

Fig. 7. MAV counties by annual aggregate social value of the three bundled ecosystem services generated by restored wetlands on WRP land (dot indicates insufficient data to construct agricultural baseline for county). 
due to insufficient data to construct their agricultural baselines (dotted in the map). Because each county has a different agricultural profile representing its baseline, the social welfare values vary by county. The ranges for these marginal values for the three focal ecosystem services are found in Table 4 . The social cost of carbon of $\$ 16.82 \mathrm{t} \mathrm{CO}_{2} \mathrm{e}$ is used for the GHG mitigation service. Multiplying these values by the number of WRP hectares located in each county, we calculate county-level estimates of the bundled values of the three services and then sum those to arrive at an aggregate value at the spatial scale of the MAV.

We assume constancy of marginal values for ecosystem services here because the scale of WRP activity has been relatively small in the $M A V$, restoring wetlands on about $3 \%$ of the approximately 7 million hectares converted to cropland. If one were to consider the benefits of restoring wetlands on all cropland in the MAV, then marginal values could possibly be non-constant (i.e., varying with quantity of wetlands) and a general equilibrium approach would be more appropriate. Nitrogen mitigation and waterfowl habitat provision are local or regional benefits whose marginal values might be expected to decline with non-marginal increases in wetlands. In contrast, GHG mitigation marginal values would not be expected to change because GHGs are global pollutants and the contribution from the MAV is extremely small in relative terms.

The differential distributions of bundled ecosystem service values across the study area counties is reflected in Fig. 7, a map displaying the value of the three ecosystem services on WRP land for each of the counties. Higher values are represented by progressively darker shades coloring the counties. Spatial variation in values across counties is due both to the amount and location of WRP lands and to the differing agricultural profiles of the counties. Annual MAV-level benefits are approximately $\$ 300$ million, although 21 of the 67 counties supply $75 \%$ of the value.

\section{Conclusions}

As public goods, ecosystem services have been traditionally underprovided due to their lack of value in the marketplace. Thus far, government conservation programs such as WRP have sought to increase the flow of these services, and they have attained a certain level of success, as this analysis demonstrates. However, increasing recognition of the importance of healthy ecosystems to human welfare creates the potential for new economic opportunities in the form of private ecosystem markets. Policymakers and business entrepreneurs need good information on the economic value of ecosystem services to guide their programs and market development efforts. This paper begins to address that need.

The Mississippi Alluvial Valley is a particularly rich ecosystem that has undergone massive change in the last 100 years and has been a recent target of restoration efforts. To examine ecosystem service values from WRP restoration in this region, we combined field data collection with secondary data collection and then linked these data with process models to calibrate expected change in those values. Unlike many other ecosystem service studies that have used topdown, landscape-level approaches, we implemented a bottom-up integration of ecosystem service function measurements, environmental modeling, and economic valuation. Additional data, currently unavailable, could enable us to build more spatial refinements into this approach, thereby capturing more accurately the heterogeneity inherent in ecosystem service production and valuation.

Focusing on three services-GHG mitigation, nitrogen mitigation, and waterfowl habitat-we estimated a lower bound for the economic value to society of restoring wetlands in the MAV. With more scientific evidence on the ecological benefits of these actions and corresponding emergence of new ecosystem service markets, that value will likely grow as currently unmonetized services, such as floodwater storage, gain their own price tags. Considering the lower bound estimate, this study's findings suggest that restoring wetlands in MAV has a social value well above the alternative use in agriculture. The largest benefits are found to flow from nitrogen mitigation, followed by GHG mitigation. Nevertheless, absent expanded public programs or new ecosystem service markets to deliver payments, landowners are being economically rational by keeping most of this land in agriculture, which currently has a higher market return. As a result, some mix of expanded payments from the public or private sector would appear to be warranted to incentivize continued wetlands restoration at a net benefit to society.

From the taxpayer perspective, the social benefits of restoring wetlands via WRP substantially exceed social costs, as the public investment pays for itself in enhanced ecosystem services in only 2 years. Again, these benefit estimates do not include other services that do not presently have a clear monetary value, but may in the future. Given the considerable surplus in conservation effects generated by WRP payments, there could be substantial opportunity for mitigation markets in the region to supplement, or possibly even replace, conservation program payments.

\section{Acknowledgements}

This work was funded under Cooperative Agreement Number SRS 06-CA-11330139-222 between the USDA Forest Service Southern Research Station and Duke University and Interagency Agreement Number NRCS 68-3A75-5-128 between USDA Natural Resources Conservation Service and the U.S. Geological Survey. We would also like to thank Diane Eckles, David Shoch, Marc Ribaudo, Skip Hyberg, Ken Richkus, Tom Moorman, Dale James, John Tirpak, Lee Moore, and Bruce McKenney. We are further indebted to Marc Ribaudo for his insightful feedback on an earlier version of this paper. Any remaining shortcomings in the study are our own.

\section{References}

Adams, D., Alig, R., McCarl, B.A., Murray, B.C., 2005. FASOMGHG Conceptual Structure and Specification: Documentation. Available at: http://agecon2.tamu.edu/people/ faculty/mccarl-bruce/papers/1212FASOMGHG_doc.pdf.

Ahearn, M.C., Boyle, K.C., Hellerstein, D.R., 2006. Designing a CV study to estimate the benefits of the CRP on grassland bird populations. In: Alberini, A., Kahn, J.R. (Eds.), Handbook on Contingent Valuation. Edward Elgar Publishing, Northampton, Massachusetts, USA, pp. 204-231.

Anderson, J.D., Parkhurst, G.M., 2004. Economic comparison of commodity and conservation program benefits: an example from the Mississippi Delta. Journal of Agricultural and Applied Economics 36 (2), 415-424.

Barbier, E.B., 2007. Valuing ecosystem services as productive inputs. Economic Policy 49, $178-229$.

Brander, L.M., Florax, R., Vermaat, J.E., 2006. The empirics of wetland valuation: a comprehensive summary and a meta-analysis of the literature. Environmental \& Resource Economics 33 (2), 223-250.

Carpenter, S.R., Caraco, N.F., Correll, D.L., Howarth, R.W., Sharpley, A.N., Smith, V.H., 1998 Nonpoint pollution of surface waters with phosphorus and nitrogen. Ecological Applications 8 (3), 559-568.

Carson, R.T., Mitchell, R.C., Hanemann, W.M., Kopp, R.J., Presser, S., Ruud, P.A., 1994. Contingent Valuation and Lost Passive Use: Damages from the Exxon Valdez. Discussion Paper No. 94-18, Resources for the Future.

Chicago Climate Exchange, 2009. CCX CFI Monthly Summary. Available at: http://www. chicagoclimatex.com/market/data/monthly.jsf. Accessed January 2009.

Chicago Climate Exchange, 2007. FAQs: CCX Afforestation Offsets. Available at: http:// www.chicagoclimatex.com/docs/offsets/Afforestation_Carbon_Offsets_faq.pdf. Accessed August 2008.

Clement, J.C., Pinay, G., Marmonier, P., 2002. Seasonal dynamics of denitrification along topohydrosequences in three different riparian wetlands. Journal of Environmental Quality 31 (3), 1025-1037.

Costanza, R., d'Arge, R., de Groot, R., Farber, S., Grasso, M., Hannon, B., et al., 1997. The value of the world's ecosystem services and natural capital. Nature 387 (6630), 253-260.

Daily, G.C. (Ed.), 1997. Nature's Services: Societal Dependence on Natural Ecosystems. Island Press, Washington, D.C.

Duriancik, L.F., Bucks, D., Dobrowolski, J.P., Drewes, T., Eckles, S.D., Jolley, L., et al., 2008. The first five years of the Conservation Effects Assessment Project. Journal of Soil and Water Conservation 63 (6), 185A-188A.

Faulkner, S.P., Richardson, C.J., 1989. Physical and chemical characteristics of freshwate wetland soils. In: Hammer, D.A. (Ed.), Constructed Wetlands for Wastewater Treatment. Lewis Publishers, Inc, Chelsea, Michigan, USA, pp. 41-72.

Faulkner, S.P., Barrow, W., Keeland, B., Walls, S., Moorman, T., Twedt, D., et al., 2008. Assessment of Ecological Services Derived from U.S. Department of Agriculture 
Conservation Programs in the Mississippi Alluvial Valley: Regional Estimates and Functional Condition Indicator Models. Interim Report. USDA NRCS.

Feather, P., Hellerstein, D., 1997. Calibrating benefit function transfer to assess the conservation reserve program. American Journal of Agricultural Economics 79 (1), 151-162.

Goolsby, D.A., Battaglin, W.A., 2001. Long-term changes in concentrations and flux of nitrogen in the Mississippi River Basin, USA. Hydrological Processes 15 (7) 1209-1226.

Groffman, P.M., Tiedje, J.M., 1989. Denitrification in north temperate forest soils spatial and temporal patterns at the landscape and seasonal scales. Soil Biology \& Biochemistry 21 (5), 613-620.

Heal, G., 2000. Nature and the Marketplace: Capturing the Value of Ecosystem Services. Island Press, Washington, D.C.

Hunter, R.G., Faulkner, S.P., et al., 2001. Denitrification potentials in restored and natural bottomland hardwood wetlands. Soil Science Society of America Journal 65 (6), $1865-1872$.

Ibendahl, G., 2004. Risk-adjusted comparison of Conservation Reserve Program versus payments for a corn-soybean farmer. Journal of Agricultural and Applied Economics 36 (2), 425-434.

Hussain, A., Munn, I.A., 2007. Hedonic analysis of hunting lease revenue and landowner willingness to provide fee-access hunting. Forest Science 53 (4), 493-506.

Ibendahl, G., 2008. An Accounting Tradeoff between WRP and Government Payments. Paper Presented at the Southern Agricultural Economics Association Annua Meeting, February 2-6, 2008.

IPCC, 2007. Climate Change 2007: Impacts, Adaptation, and Vulnerability. Fourth Assessment Report, Working Group II. Intergovernmental Panel on Climate Change. Available at: http://www.ipcc-wg2.org/index.html.

King, S.L., Twedt, D.J., Wilson, R.R., 2006. The role of the Wetland Reserve Program in conservation efforts in the Mississippi River Alluvial Valley. Wildlife Society Bulletin 34 (4), 914-920.

Kramer, R.A., 2007. Economic valuation of ecosystem services. In: Pretty, J.N., Ball, A.S Orr, D., Benton, T., Lee, D.R., Guivant, J.S. (Eds.), Sage Handbook on Environment and Society. Sage Publications Ltd, London, pp. 172-180.

Loomis, J.B., Rosenberger, R.S., 2006. Reducing barriers in future benefit transfers: needed improvements in primary study design and reporting. Ecological Economics 60 (2), 343-350

Lowrance, R., Todd, R., Fail, J., Hendrickson, O., Leonard, R., Asmussen, L., 1984. Riparian forests as nutrient filters in agricultural watersheds. BioScience 34 (6), 374-377.

Lowrance, R.R., Isenhart, T.M., Gburek, W., Shields Jr., F.D., Wigington Jr., P.J., Dabney, S.M 2006. Landscape management practices. In: Schnepf, M., Cox, C. (Eds.), Environmental Benefits of Conservation on Cropland: The Status of Our Knowledge. Soil and Water Conservation Society, Ankeny, Iowa, USA

Millennium Ecosystem Assessment, 2005. Ecosystems and Human Well-Being: Synthesis. Island Press, Washington, DC.

Mississippi River/Gulf of Mexico Water Nutrient Task Force, 2007. Gulf Hypoxia Action Plan. Available at: www.epa.gov/msbasin/taskforce/pdf/2008draft_actionplan.pdf. Mitsch, W.J., Gosselink, J.G., 2007. WetlandsFourth Ed. John Wiley \& Sons, Hoboken, NJ.

Mitsch, W.J., Day, J.W., Gilliam, J.W., Groffman, P.M., Hey, D.L., Randall, G.W., et al., 2001 Reducing nitrogen loading to the Gulf of Mexico from the Mississippi River Basin: strategies to counter a persistent ecological problem. BioScience 51 (5), 373-388

Morgan, C., Wolverton, A., 2005. Water Quality Trading in the United States. Working Paper No. 05-07, U.S. Environmental Protection Agency, National Center fo Environmental Economics. Available at: http://yosemite.epa.gov/ee/epa/eed.nsf/ ffb05b5f4a2cf40985256d2d00740681/3e026cbb6a9956918525702f005e383c/ \$FILE/2005-07.pdf.

Murray, B.C., McCarl, B.A., Lee, H.C., 2004. Estimating leakage from forest carbon sequestration programs. Land Economics 80 (1), 109-124.

Murray, B.C., Sohngen, B., Ross, M.T., 2007. Economic consequences of consideration of permanence, leakage and additionality for soil carbon sequestration projects. Climatic Change 80 (1-2), 127-143.

Murray, B.C., Jenkins, W.A., Kramer, R.A., Faulkner, S.P., 2009. Valuing Ecosystem Services from Wetlands Restoration in the Mississippi Alluvial Valley. Report No. 09-02, Nicholas Institute for Environmental Policy Solutions. Duke University. Available at: http://www.nicholas.duke.edu/institute/msvalley.pdf.

National Research Council, 2005. Valuing Ecosystem Services: Toward Better Environmental Decision-Making. National Academies Press, Washington, D.C.

Novak, J.M., Stone, K.C., Szogi, A.A., Watts, D.W., Johnson, M.H., 2004. Dissolved phosphorus retention and release from a coastal plain in-stream wetland. Journal of Environmental Quality 33 (1), 394-401.

Peterjohn, W.T., Correll, D.L., 1984. Nutrient dynamics in an agricultural watershed observations on the role of a riparian forest. Ecology 65 (5), 1466-1475.

Potter, S.R., Andrews, S., Atwood, J.D., Kellogg, R.L., Lemunyon, J., Norfleet, L., et al., 2006a. Model Simulation of Soil Loss, Nutrient Loss, and Change in Soil Organic Carbon Associated with Crop Production. U.S. Department of Agriculture Natura
Resources Conservation Service. Available at: http://www.nrcs.usda.gov/Technical/ nri/ceap/croplandreport/.

Potter, S.R., Atwood, J.A., Pitts, T.A., 2006b. The National Nutrient Loss and Soil Carbon Database. Texas Agriculture Experiment Station Blackland Research Center. Available at: ftp.brc.tamus.edu/pub/nnlsc/.

Reddy, K.R., Kadlec, R.H., Flaig, E., Gale, P.M., 1999. Phosphorus retention in streams and wetlands: a review. Critical Reviews in Environmental Science and Technology 29 (1), 83-146.

Rhyne, J., Munn, I.A., 2007. Factors Determining per Acre Market Value of Hunting Leases on Sixteenth Section Lands in Mississippi. Report no. FO-0352. Mississippi State University.

Ribaudo, M.O., Heimlich, R., Claassen, R., Peters, M., 2001. Least-cost management of nonpoint source pollution: source reduction versus interception strategies for controlling nitrogen loss in the Mississippi Basin. Ecological Economics 37 (2), 183-197.

Ribaudo, M.O., Heimlich, R., Peters, M., 2005. Nitrogen sources and Gulf hypoxia: potential for environmental credit trading. Ecological Economics 52 (2) 159-168.

Ribaudo, M.O., Greene, C. Hansen, L. Hellerstein, D., 2008. The Use of Markets to Increase Private Investment in Environmental Stewardship. Economic Research Report No. ERR-64. USDA Economic Research Service. Available at: http://www.ers. usda.gov/Publications/ERR64/.

Ricketts, T.H., Daily, G.C., Ehrlich, P.R., Michener, C.D., 2004. Economic Value of Tropica Forest to Coffee Production. Proceedings of the National Academy of Sciences of the United States of America 101 (34), 12,579-12,582.

Rosenberger, R.S., Loomis, J.B. 2001. Benefit Transfer of Outdoor Recreation Use Values: A Technical Document Supporting the Forest Service Strategic Plan (2000 Revision). Fort Collins, CO, U.S. Department of Agriculture, Forest Service, Rocky Mountain Research Station: 59.

Rosenberger, R.S., Loomis, J.B., 2003. Benefit transfer. In: Champ, P.A., Boyle, K.J., Brown, T.C. (Eds.), A Primer on Nonmarket Valuation. Kluwer Academic Publishers, Dordrecht, The Netherlands, pp. 445-482.

Shoch, D.T., Kaster, G., Hohl, A., Souter, R., 2009. Carbon sequestration potential of bottomland hardwood afforestation in the Lower Mississippi Valley, U.S.A. Wetlands 29 (2), 535-542.

Smith, J.E., Heath, L.S., Skog, K.E., Birdsey, R.A., 2006. Methods for Calculating Forest Ecosystem and Harvested Carbon with Standard Estimates for Forest Types of the United States. General Technical Report No. NE-343, U.S. Department of Agriculture Forest Service, Northeastern Research Station. Available at: http://www.fs.fed.us/ ne/durham/4104/papers/ne_gtr343.pdf.

Toman, M., 1998. Special section: forum on valuation of ecosystem services: why not to calculate the value of the world's ecosystem services and natural capital. Ecological Economics 25 (1), 57-60.

Twedt, D.J., Loesch, C.R., 1999. Forest area and distribution in the Mississippi alluvial valley: implications for breeding bird conservation. Journal of Biogeography 26 (6), $1215-1224$.

U.S. Department of Agriculture-National Agricultural Statistics Service (USDA-NASS), 2009. Quick Stats, State and County Data. Available at: http://www.nass.usda.gov/ QuickStats/Create_County_All.jsp.

U.S. Department of Agriculture-Natural Resources Conservation Service (USDA-NRCS) 2007. Farm Bill 2002, Wetlands Reserve Program: Key Points. Available at: http:/ www.nrcs.usda.gov/Programs/WRP/2007_ContractInfo/2007WRPKeyPoints.pdf. Accessed June 6, 2008.

U.S. Department of Agriculture-Natural Resources Conservation Service (USDA-NRCS) 2008. Wetland Reserve Program. Available at: http://www.nrcs.usda.gov/Programs/ WRP/. Accessed June 16, 2008.

U.S. Department of Labor-Bureau of Labor Statistics (BLS), 2009. CPI Inflation Calculator. Available at: http://data.bls.gov/cgi-bin/cpicalc.pl.

U.S. Environmental Protection Agency (USEPA), 2002. A Framework for the Economic Assessment of Ecological Benefits. Available at: http://www.epa.gov/OSA/spc/pdfs/ feaeb3.pdf.

U.S. Environmental Protection Agency (USEPA), 2008. EPA Analysis of the LiebermanWarner Climate Security Act of 2008: S.2191 in the 110th Congress. Available at: http://www.epa.gov/climatechange/downloads/s2191_EPA_Analysis.pdf.

Ullah, S., Faulkner, S.P., 2006a. Denitrification potential of different land-use types in an agricultural watershed, lower Mississippi valley. Ecological Engineering 28 (2), 131-140

Ullah, S., Faulkner, S.P., 2006b. Use of cotton gin trash to enhance denitrification in restored forested wetlands. Forest Ecology and Management 237 (1-3), 557-563.

Williams, J.R., Jones, C.A., Kiniry, J.R., Spanel, D.A., 1989. The EPIC crop growth-model Transactions of the Asae 32 (2), 497-511.

Wilson, M.A., Hoehn, J.P., 2006. Valuing environmental goods and services using benefit transfer: the state-of-the art and science. Ecological Economics 60 (2), 335-342.

Woodward, R.T., Wui, Y.-S., 2001. The economic value of wetland services: a metaanalysis. Ecological Economics 37 (2), 257-270. 